\title{
Site-Specific Migration and Neuronal Differentiation of Human Neural Progenitor Cells after Transplantation in the Adult Rat Brain
}

\author{
Rosemary A. Fricker, ${ }^{1,2}$ Melissa K. Carpenter, ${ }^{3,4}$ Christian Winkler, ${ }^{1}$ Corinne Greco, ${ }^{3}$ Monte A. Gates, ${ }^{1,2}$ and \\ Anders Björklund 1
}

${ }^{1}$ Wallenberg Neuroscience Center, Division of Neurobiology, Lund University, S-223 Lund, Sweden, ${ }^{2}$ Department of

Neurology, Harvard Medical School, Children's Hospital, Boston, Massachusetts 02115, ${ }^{3}$ CytoTherapeutics, Lincoln, Rhode Island 02865, and ${ }^{4}$ Geron Corporation, Menlo Park, California 94025

\begin{abstract}
Neural progenitor cells obtained from the embryonic human forebrain were expanded up to $10^{7}$-fold in culture in the presence of epidermal growth factor, basic fibroblast growth factor, and leukemia inhibitory growth factor. When transplanted into neurogenic regions in the adult rat brain, the subventricular zone, and hippocampus, the in vitro propagated cells migrated specifically along the routes normally taken by the endogenous neuronal precursors: along the rostral migratory stream to the olfactory bulb and within the subgranular zone in the dentate gyrus, and exhibited site-specific neuronal differentiation in the granular and periglomerular layers of the bulb and in the dentate granular cell layer. The cells exhibited substantial migration also within the non-neurogenic region, the striatum, in a seem-
\end{abstract}

ingly nondirected manner up to $\sim 1-1.5 \mathrm{~mm}$ from the graft core, and showed differentiation into both neuronal and glial phenotypes. Only cells with glial-like features migrated over longer distances within the mature striatum, whereas the cells expressing neuronal phenotypes remained close to the implantation site. The ability of the human neural progenitors to respond in vivo to guidance cues and signals that can direct their differentiation along multiple phenotypic pathways suggests that they can provide a powerful and virtually unlimited source of cells for experimental and clinical transplantation.

Key words: progenitor cells; human; transplantation; neuron; subventricular zone; dentate gyrus; striatum
The limited capacity for structural repair in the mammalian brain is in part explained by the inability of the mature CNS to generate new cellular elements in response to damage. Cell transplantation offers a possibility to circumvent this limitation. Both rodent and primate experiments show that neuroblasts and young postmitotic neurons obtained from defined parts of the neuraxis during development can survive, mature, and grow extensive functional axonal connections after transplantation to brain-damaged recipients, and both structurally and functionally replace lost neurons in the mature brain (for review, see Dunnett and Björklund, 1994). Because of the limited migratory capacity of the differentiated cells, however, these types of implants are unable to integrate into the cellular architecture of the host.

Previous studies have shown that less differentiated precursor cells, taken at premigratory stages of neuronal development, can make use of available substrates or pathways for migration, mix with endogenous pools of precursors, and participate in ongoing neurogenesis, both during development (McConnell, 1988; Gao and Hatten, 1994; Zigova et al., 1996) and in areas of the mature brain, the anterior subventricular zone (SVZa), and the hip-

\footnotetext{
Received Dec. 7, 1998; revised April 15, 1999; accepted April 27, 1999.

This study was supported by the Wellcome Trust, the Swedish Medical Research Council, the Wenner Gren Foundation, and CytoTherapeutics Inc. We thank Åke Seiger and Lars Wahlberg for the supply of human embryonic tissue; Tomas Björklund, Cristina Ciornei, Alicja Flasch, Birgit Haraldsson, Jennifer Jackson, Ulla Jarl, Anna Karin Olden, Sandy Sherman, and Gertrude Stridsberg for excellent technical assistance; and Joe Hammang for useful discussion and comments on this manuscript. The Hu antibody was a generous gift from Dr. Steven A. Goldman, and the DARPP-32 antibody was a generous gift from Dr. Paul Greengard.

Correspondence should be addressed to Dr. Rosemary Fricker, Department of Neurology, Division of Neuroscience, Harvard Medical School, 350 Enders Building, Children's Hospital, 330 Longwood Avenue, Boston, MA 02115.

Copyright (C) 1999 Society for Neuroscience 0270-6474/99/195990-16\$05.00/0
}

pocampal dentate gyrus, where neurogenesis continues into adulthood (Lois and Alvarez-Buylla, 1993; Vicario-Abejon et al., 1995). Similarly, mixed precursor cell populations, injected in utero into the developing forebrain, integrate across the ventricular wall and undergo site-specific migration and neuronal differentiation in widespread brain regions (Brüstle et al., 1995; Campbell et al., 1995; Fishell, 1995), suggesting that undifferentiated progenitors may be an interesting source of cells for intracerebral transplantation.

Recently, neural progenitors with the capacity to give rise to all major cell types of the mature CNS have been isolated from the developing or adult CNS (Weiss et al., 1996b; Alvarez-Buylla, 1997; Luskin et al., 1997; Ray et al., 1997). They become more restricted in number during development and remain as a small, relatively quiescent population of dividing cells in the subventricular regions of the adult CNS. These neural progenitors can be grown in vitro in the presence of either epidermal growth factor (EGF) or basic fibroblast growth factor (bFGF, FGF-2), as a population of continuously dividing progenitors capable of differentiating into both neurons and glia (Murphy et al., 1990; Reynolds and Weiss, 1992a,b, 1996; Richards et al., 1992; Ray et al., 1993; Vescovi et al., 1993; Sensenbrenner et al., 1994; Palmer et al., 1995). Cells isolated from the rat hippocampus in the presence of bFGF have been shown to express region-specific migration and neuronal differentiation after transplantation to the adult rat brain (Gage et al., 1995; Suhonen et al., 1996). Embryonic mouse or rat forebrain progenitors expanded in the presence of EGF, by contrast, develop into predominantly glial phenotypes in vivo, as observed after transplantation to the adult rat spinal cord (Hammang et al., 1997) or the developing rat forebrain (Winkler et al., 1998). 
Here, we have examined the question of whether progenitors isolated from the developing human CNS can exhibit in vivo neurogenic properties after implantation into the brain of adult recipients. Cells obtained from the forebrain of 6.5- to 9-week-old human fetuses were maintained as continuously dividing cultures in the presence of EGF, bFGF, and leukemia inhibitory growth factor (LIF). Cells expanded $10^{3}-10^{7}$-fold in culture (over 9-21 passages) survived well after transplantation to both neurogenic and non-neurogenic sites; cells contained within these grafts showed migration, integration, and site-specific differentiation into both neurons and glia.

\section{MATERIALS AND METHODS}

Generation and in vitro culture of human progenitor cells. Generation of the human progenitor cell lines has been described previously (Carpenter et al., 1999). Embryonic brain tissue was obtained from one 6.5 week and one 9 week embryo (post-conception) under compliance with National Institutes of Health guidelines, Swedish government guidelines, and the local ethics committee, and appropriate consent forms were used. Tissue from the forebrain was dissected in sterile saline and transferred to N2 medium, a defined DMEM/F12-based medium (Life Technologies, Grand Island, NY) containing $0.6 \%$ glucose, $25 \mu \mathrm{g} / \mathrm{ml}$ human insulin, $100 \mu \mathrm{g} / \mathrm{ml}$ human transferrin, $20 \mathrm{nM}$ progesterone, $60 \mu \mathrm{M} \mathrm{pu}-$ trescine, $30 \mathrm{~nm}$ selenium chloride, $2 \mathrm{~nm}$ glutamine, $3 \mathrm{~mm}$ sodium bicarbonate, $5 \mathrm{~mm}$ HEPES, and $2 \mu \mathrm{g} / \mathrm{ml}$ heparin (Sigma, St. Louis, MO). The tissue was dissociated using a standard glass homogenizer, and the dissociated cells were grown on uncoated plastic T75 flasks in N2 medium containing human EGF (hEGF, $20 \mathrm{ng} / \mathrm{ml}$; Life Technologies), human basic FGF (hbFGF, $20 \mathrm{ng} / \mathrm{ml}$; Life Technologies), and human LIF (hLIF) $(10 \mathrm{ng} / \mathrm{ml}, \mathrm{R}+\mathrm{D}$ Systems, UK), at a density of $\sim 100,000$ cells $/ \mathrm{ml}$.

The cells grew as free-floating clusters ("neurospheres"), and were prevented from attachment by gently knocking the flasks each day. Any cells that adhered to the plastic and began to extend processes were not removed by this procedure and therefore were not carried through to the next passage. The spheres were passaged by mechanical dissociation every $7-10 \mathrm{~d}$ and reseeded as single cells at a density of $\sim 100,000$ cells $/ \mathrm{ml}$. The cells used for transplantation (the $6.5 \mathrm{FBr}$ and $9 \mathrm{FBr}$ cultures) had been expanded over 9-21 passages, which corresponds to a total increase in cell numbers of $\sim 10^{3}$ at 9 passages to at least $10^{7}$ at 21 passages (Carpenter et al., 1999).

Labeling methods and preparation of cells for transplantation. To enable the detection of the cells in vivo, cultures were labeled with $1 \mu \mathrm{M}$ bromodeoxyuridine (BrdU), which was added to the culture medium 48 $\mathrm{hr}$ before the preparation of the cells for transplantation. This resulted in $\sim 80 \%$ labeling efficiency, with no apparent changes in growth rate of the spheres.

Cells were taken for transplantation 4-5 d after the last passage as small spheres of 5-30 cells. The spheres were collected by centrif ugation at $1000 \mathrm{rpm}$ for $3 \mathrm{~min}$ and resuspended in $1 \mathrm{ml} \mathrm{DMEM} / \mathrm{F} 12$ medium. To check the cell viability, an aliquot of the sphere suspension was removed and mixed with trypan blue. After this was ascertained, a second cell count was performed by triturating the trypan blue aliquot to give single cells. The sphere suspension was centrifuged a second time and resuspended in a smaller volume to give the equivalent of $\sim 100,000 \mathrm{cells} / \mu \mathrm{l}$.

Transplantation. Adult female Sprague Dawley rats (B\&K Universal, Stockholm, Sweden), weighing $\sim 250 \mathrm{gm}$ at the beginning of the study, were used. They were caged in groups of two and maintained on a $12 \mathrm{hr}$ light/dark cycle with constant temperature and humidity, with ad libitum food and water. The animals were immunosuppressed throughout the experiment by daily injections of $10 \mathrm{mg} / \mathrm{kg}$ cyclosporin, beginning $1 \mathrm{~d}$ before transplantation.

Stereotaxic surgery was performed under deep equithesin anesthesia ( $3 \mathrm{ml} / \mathrm{kg}$ body weight, i.p.). Rats received $1 \mu \mathrm{l}$ cell suspension bilaterally in either the SVZa, rostral migratory stream (RMS), or hippocampus, or $2 \mu \mathrm{l}$ in the striatum, according to the following coordinates: SVZa, anterior $(\mathrm{A})=+1.6$, lateral $(\mathrm{L})= \pm 1.5$, ventral $(\mathrm{V})=-4.2$; RMS, $\mathrm{A}=$ $+3.7, \mathrm{~L}= \pm 1.5, \mathrm{~V}=-5.0$; hippocampus, $\mathrm{A}=-3.6, \mathrm{~L}= \pm 2.0, \mathrm{~V}=$ $-3.0,-2.6$; striatum, $\mathrm{A}=0.6, \mathrm{~L}= \pm 2.8, \mathrm{~V}=-4.8,-4.2$. The tooth bar was set at -2.3 , and all ventral coordinates were taken from dura. Cells were implanted via a glass capillary (inner diameter $\sim 70 \mu \mathrm{m}$ ) attached to a $2 \mu \mathrm{l}$ Hamilton syringe. For the SVZa transplants, 100,000 cells from the $6.5 \mathrm{FBr}$ cell line were transplanted, and the brains were analyzed after 6 weeks $(n=10)$. For the RMS transplants, 100,000 cells were transplanted, and the brains were analyzed at either 2 weeks $(6.5 \mathrm{FBr}, n=10$; $9 \mathrm{FBr}, n=4)$ or 6 weeks $(6.5 \mathrm{FBr}, n=10)$. Both cell lines were transplanted to either the striatum $(200,000$ cells $)$ or hippocampus $(100,000$ cells), and the brains were analyzed at either 2 or 6 weeks $(n=10$ per group).

Tissue processing. At either 2 or 6 weeks after transplantation, rats were terminally anesthetized with $5 \%$ chloral hydrate and transcardially perfused with $0.1 \mathrm{M}$ PBS followed by 5 min rapid fixation with ice-cold $4 \%$ paraformaldehyde (PFA) in $0.1 \mathrm{M}$ phosphate buffer. Brains were removed and placed in PFA overnight, before being transferred to $25 \%$ sucrose in PBS. Coronal or sagittal sections were cut on a freezing microtome at a thickness of $30 \mu \mathrm{m}$. In each case, eight series were collected for further processing.

Immunocytochemistry. For BrdU labeling, all sections were pretreated with $1 \mathrm{M} \mathrm{HCl}$ for $30 \mathrm{~min}$ at $65^{\circ} \mathrm{C}$. Sections were incubated in primary antibodies for $36 \mathrm{hr}$ at $4^{\circ} \mathrm{C}$. All primary antibodies were diluted in $0.02 \mathrm{M}$ potassium PBS (KPBS) containing 5\% normal serum of the species in which the secondary antibody was raised and $0.25 \%$ Triton X-100, except for $32 \mathrm{kDa}$ dopamine- and cAMP-regulated phosphoprotein (DARPP$32)$ and $\gamma$-amino decarboxylase $\left(\mathrm{GAD}_{67}\right)$ in which Triton $\mathrm{X}-100$ was omitted. Antibodies used in this study were BrdU rat monoclonal (1:100, Chemicon, Temecula, CA), mouse monoclonal (1:25, Becton Dickinson, Franklin Lakes, NJ,), $\beta$-tubulin-III (1:400, Sigma), calbindin (1:1000, Sigma), DARPP-32 (1:20,000; Dr. P. Greengard, Rockefeller), GAD 67 (1:1000, Chemicon), glial fibrillary acidic protein (GFAP, 1:500, Dakopatts), RNA binding protein (Hu, 1:1000; Dr. S. Goldman, Cornell), neuronal nuclei (NeuN, 1:100, Chemicon), tyrosine hydroxylase (TH, 1:500, PelFreeze, Rogers, AR), Vimentin (VIM, 1:25, Dakopatts), and human-specific tau (hTau, 1:100, Calbiochem, La Jolla, CA). For all immunohistochemical procedures, adjacent sections served as negative controls and were processed using identical procedures, except for incubation without the primary antibody in each case.

For fluorescent double-labeling immunocytochemistry, after rinses in KPBS containing $2 \%$ of the normal sera, sections were incubated in the secondary antibodies (1:200). For rat anti-BrdU this was donkey anti-rat conjugated to FITC or Cy2 (Jackson); for mouse anti-BrdU, donkey anti-mouse conjugated to FITC or Cy2 (Jackson); for all other primary antibodies raised in mouse, rat-absorbed biotinylated horse anti-mouse (Vector); and for all primary antibodies raised in rabbit, biotinylated swine anti-rabbit (Dakopatts). All secondaries were diluted in KPBS containing $2 \%$ normal serum, and sections were reacted for $2 \mathrm{hr}$ at room temperature in the dark. After three rinses in KPBS, sections were reacted with streptavidin conjugated to Cy3 (Jackson) for a further $2 \mathrm{hr}$ at room temperature in the dark.

For immunohistochemistry with hTau, sections were pretreated with $3 \% \mathrm{H}_{2} \mathrm{O}_{2}$ in $10 \%$ methanol to quench endogenous peroxidase activity. Incubation in the primary antibody was performed in KPBS containing $5 \%$ normal horse serum and $0.25 \%$ Triton X-100 for $36 \mathrm{hr}$ at $4^{\circ} \mathrm{C}$. After three rinses in KPBS, sections were incubated in the secondary antibody: rat-absorbed biotinylated horse anti-mouse (Vector) in KPBS containing $2 \%$ normal horse serum for $2 \mathrm{hr}$ at room temperature. Further washing in KPBS was followed by incubation with avidin-biotin-peroxidase complex (Vectastain, Vector), for $1.5 \mathrm{hr}$ at room temperature. 3.3Diaminobenzidine (Sigma) in $0.03 \% \mathrm{H}_{2} \mathrm{O}_{2}$ in KPBS was used as the chromogen.

The sections were mounted on chrome-alum-coated slides, and the fluorescent sections were coverslipped using polyvinyl alcohol-1,4diazabicyclo[2,2,2] octane mounting medium. The hTau slides were dehydrated in ascending alcohols and coverslipped using DPX mountant.

Confocal microscopy. Colocalization of BrdU with neuronal and glial markers was conducted by confocal microscopy to enable exact definition of each of the antibodies, using a Bio-Rad MRC1024UV confocal scanning light microscope. Double-labeled cells were always verified, both by collecting serial sections of 1-2 $\mu \mathrm{m}$ throughout the specimen, and by eye, using an Olympus binocular microscope. In all figures, all double-labeled cells that are denoted were identified in this way.

\section{RESULTS}

\section{In vitro characteristics of the transplanted cells}

Two different human progenitor cell cultures obtained post mortem from the forebrain of one 6.5 week $(6.5 \mathrm{FBr})$ and one 9 week (9FBr) embryo were analyzed. The cells were cultured in the presence of EGF, bFGF and LIF and passaged every 7-10 d. In 
these cultures bFGF was necessary to maintain continuous cell proliferation over extended time periods, and this effect was further enhanced by the addition of LIF. Parallel in vitro experiments (Carpenter et al., 1999) indicate that LIF promotes the sustained proliferation of the human progenitors in the neurosphere cultures. Moreover, in agreement with previous findings (Satoh and Yoshida, 1997), the proportion of cells that differentiated into neurons appeared to be increased in the presence of LIF.

The in vitro characteristics of the $6.5 \mathrm{FBr}$ and $9 \mathrm{FBr}$ progenitor cell cultures have been presented in detail elsewhere (Carpenter et al., 1999). Briefly, both cultures showed a growth rate that was similar to each other and to other human progenitor cell cultures derived from different gestational ages. Cells within undifferentiated spheres were immunopositive for the immature cell marker nestin and were shown to incorporate BrdU, indicative of cell division. To assess the differentiation capacity of these cells, dissociated single cells were plated onto poly-ornithine-coated glass coverslips and cultured for 12-14 d in N2 medium containing $1 \%$ FBS. On differentiation, both cell cultures demonstrated the capacity to form neurons, astrocytes, and oligodendrocytes. Immunohistochemistry using an antibody to GFAP revealed a range of $15-55 \%$ astrocytes present in both the $6.5 \mathrm{FBr}$ and $9 \mathrm{FBr}$ cultures between passage 5 (P5) and P35. An antibody to $\beta$-tubulin isotype III was used to detect neurons. At P5 the $6.5 \mathrm{FBr}$ cultures generated more $\beta$-tubulin-III-positive cells than the $9 \mathrm{FBr}$ cells (37 vs 20\%, respectively). At P20-P30 (150-300 d in vitro), the percentage of neurons had decreased to $\sim 15 \%$ in both cultures.

\section{Survival and differentiation after transplantation to the adult rat brain}

Cells from the $6.5 \mathrm{FBr}$ and $9 \mathrm{FBr}$ cultures were transplanted, under immunosuppression, into two neurogenic sites: the dentate gyrus of the hippocampus and the SVZa and its associated RMS, as well as to a non-neurogenic site, the striatum. Transplantation was performed using cells that had been passaged 9-21 times. The cells were labeled with BrdU during the last $48 \mathrm{hr}$ before transplantation. This resulted in $\sim 80 \%$ labeling efficiency and enabled analysis of the grafts by fluorescent immunohistochemistry using a double-labeling technique for BrdU in combination with specific neuronal and glial markers. In addition, hTau was used to identify the grafted cells.

In all animals, BrdU-positive transplanted cells were identified in all graft sites, at both 2 and 6 weeks after transplantation. Similarly, staining with the human-specific tau antibody revealed cellular and axonal profiles at all transplant sites, indicating graft survival in all cases. Extensive migration of BrdU-labeled cells, as described below, were seen in all animals where the graft deposits had been correctly placed in the RMS, SVZa, or hippocampus, respectively. No evidence of tumor formation was observed.

The transplants from both cell cultures $(6.5 \mathrm{FBr}$ and $9 \mathrm{FBr})$, regardless of the number of passages, were indistinguishable in terms of graft survival, migrational patterns, and phenotypic differentiation of the transplanted cells. Control transplants of cells that had been killed by freeze-thawing before transplantation showed no transfer of the BrdU marker to the host cells, which is in agreement with previous reports (Gage et al., 1995; Suhonen et al., 1996).

\section{The subventricular zone and rostral migratory stream}

Single deposits of 100,000 cells were deposited in or close to the SVZa, just ventral to the corpus callosum, or just above the RMS midway between the SVZa and the olfactory bulb. In the SVZa a core of BrdU-positive cells was located close to the ventricular ependyma, extending in some cases into the white matter of the overlying corpus callosum (Fig. 1A) (6 weeks survival). Cells were seen to leave the transplantation site in a stream of rostral migration (Fig. $1 B$ ) after the RMS, i.e., along the path of endogenous progenitors toward the olfactory bulb. Once they reached the bulb, BrdU-positive cells left the migratory stream, becoming dispersed throughout the subependymal, granular (Fig. 1C,D), and glomerular cell layers. The cells within the olfactory bulb were more weakly BrdU-labeled than the cells in the SVZa (which were uniformly highly labeled), suggesting that the labeled cells had undergone further cell division on their route to the bulb, similar to the endogenous progenitors from the SVZa (Menezes et al., 1995).

In the RMS transplants the deposits of BrdU-labeled cells were localized just above, and occasionally within, the RMS itself (see Fig. $4 A$ ). At 2 weeks after transplantation the cells remained clustered at the graft site, and there was very little migration from the graft core. Thus only few cells were observed rostral and caudal to the graft placement at this time point. Six weeks after grafting, cells were seen to have migrated rostrally toward the olfactory bulb (see Fig. $4 B$ ) and into the granular and periglomerular layers (see Fig. $4 C-F$ ).

The immature cell marker VIM was used to delineate the SVZa and RMS along which BrdU-positive cells were seen in their migratory stream (Fig. 2A). BrdU-positive cells were not VIM positive. The vast majority of the BrdU-labeled nuclei did not diverge from the RMS; however, in the region adjacent to the transplant core, occasional cells could be seen migrating dorsally toward the overlying cortex (data not shown). Some of the cells migrating within the RMS were double-labeled with the early neuronal markers $\mathrm{Hu}$ (Fig. $2 B$ ) and $\beta$-tubulin-III (see Fig. $4 B$ ). Both of these markers, which identify both early differentiated neuronal precursors and mature neurons, are known to be expressed by the endogenous progenitors from the SVZa as they migrate along the RMS (Barami et al., 1995; Menezes et al., 1995). The presence of these markers thus indicates their early commitment to a neuronal phenotype. None of the BrdU-positive cells within the SVZa or RMS stained positively for the NeuN marker. Within the olfactory bulb, the majority of BrdU-labeled cells, both in the deeper layers and in the periglomerular layer, were $\mathrm{Hu}$ positive (Figs. $2 C, 4 C$ ), and approximately half of the BrdU-positive cells were also double-labeled with the more mature neuronal marker NeuN (Fig. 2D,E), indicating a progressive maturation of the cells toward a neuronal phenotype as they entered the bulb. Many of the BrdU-labeled cells, within both the granule cell layer and periglomerular layer, also expressed the GABA-sythesizing enzyme $\mathrm{GAD}_{67}$ (see Fig. $4 D, E$ ). TH, which is a characteristic feature of the dopaminergic periglomerular neurons, was clearly expressed in some of the BrdU-labeled cells within the periglomerular layer (Fig. $4 F$, arrowheads and inset). None of the BrdU-labeled cells stained positively for the glial marker GFAP, neither within the astrocyte-rich RMS (see Fig. $9 A$ ) nor within the olfactory bulb (see Fig. 9B). In addition, no cells were double-labeled with BrdU and the receptor phosphoprotein DARPP-32, which is present in the medium spiny neurons of the striatum but not normally expressed in neurons of the olfactory bulb. Table 1 gives a semiquantitative summary of neuronal and glial differentiation of the transplanted cells within the RMS and the olfactory bulb.

Using a human-specific antibody to the cytoskeletal protein 

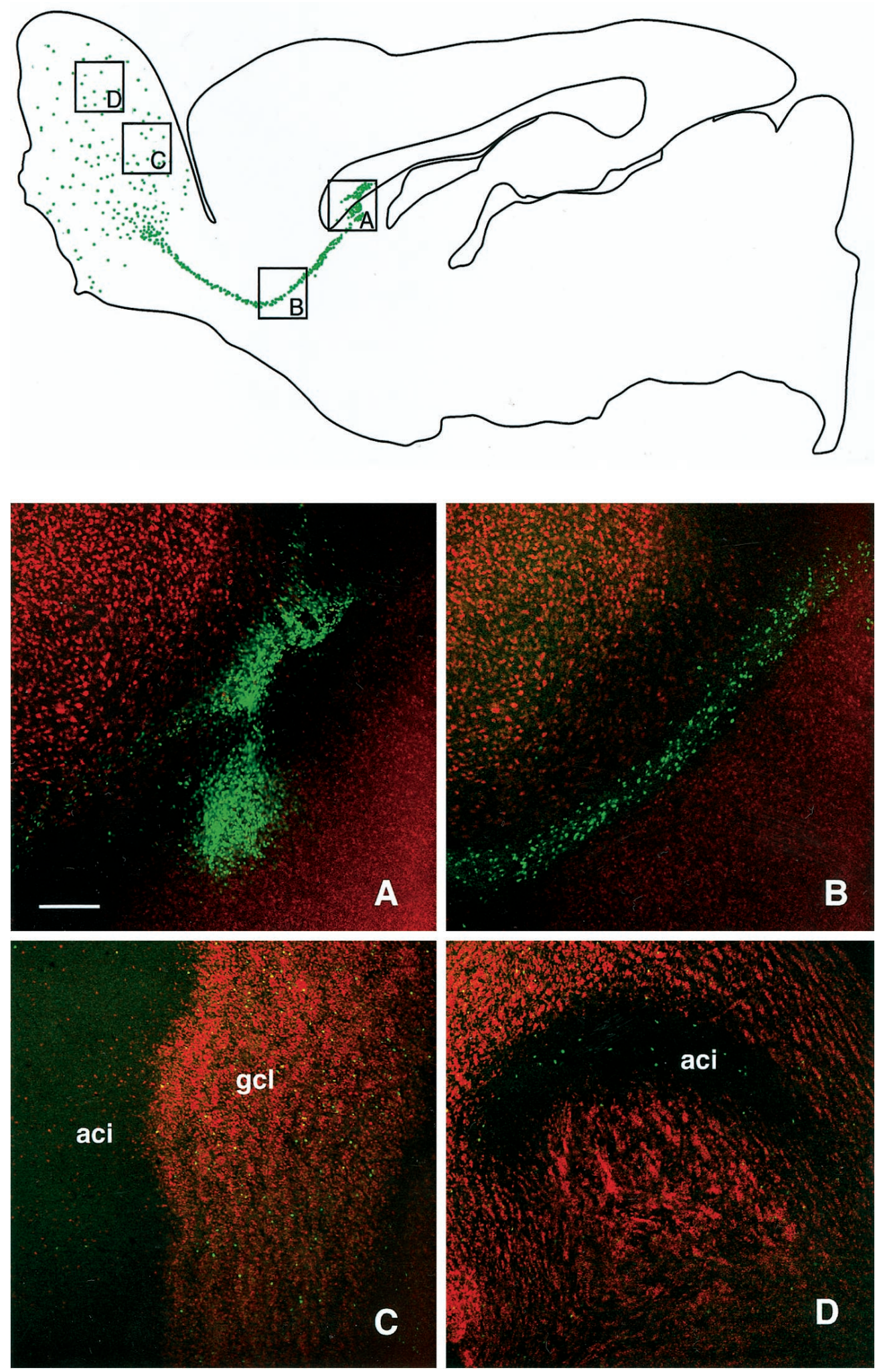

Figure 1. Low-power illustration of a transplant in the SVZa in a sagittal section, analyzed at 6 weeks after transplantation, shows an overview of the injection site of BrdU-labeled cells (green) and their distribution throughout the RMS. In the olfactory bulb, the cells were found dispersed through all layers. $A-D$, Grafted cells at different sites (indicated in the top panel), with BrdU-labeled cells shown in green and the NeuN shown in red. Double-labeled cells present in the bulb display a yellow color $(C, D)$. $A$, Transplant core; $B$, cells migrating along the RMS; $C, D$, cells in the granule cell layer of the olfactory bulb. Scale bar, $250 \mu \mathrm{m}$. aci, Intrabulbar portion of the anterior commissure; $g c l$, granule cell layer.

tau, positive staining was observed at the injection site in both cellular and axonal profiles (Fig. 3A). Typically, cells that remained at the graft core or migrated only a short distance from the implantation site had developed axons that projected laterally into either the corpus callosum or striatum adjacent to the transplant (Fig. 3A,B). Tau-positive cells were distributed along the RMS, several millimeters from the graft site (Fig. 3C,D). These cells often showed a short leading process, oriented in the direction of the RMS (Fig. 4). Small tau-positive profiles were observed in the deeper layers of the olfactory bulb, and occasionally mature cells with extensive processes were found in this region (Fig. 3E,F). High background from the immunohistochemical procedure precluded the identification of tau-positive profiles in the periglomerular layer. 

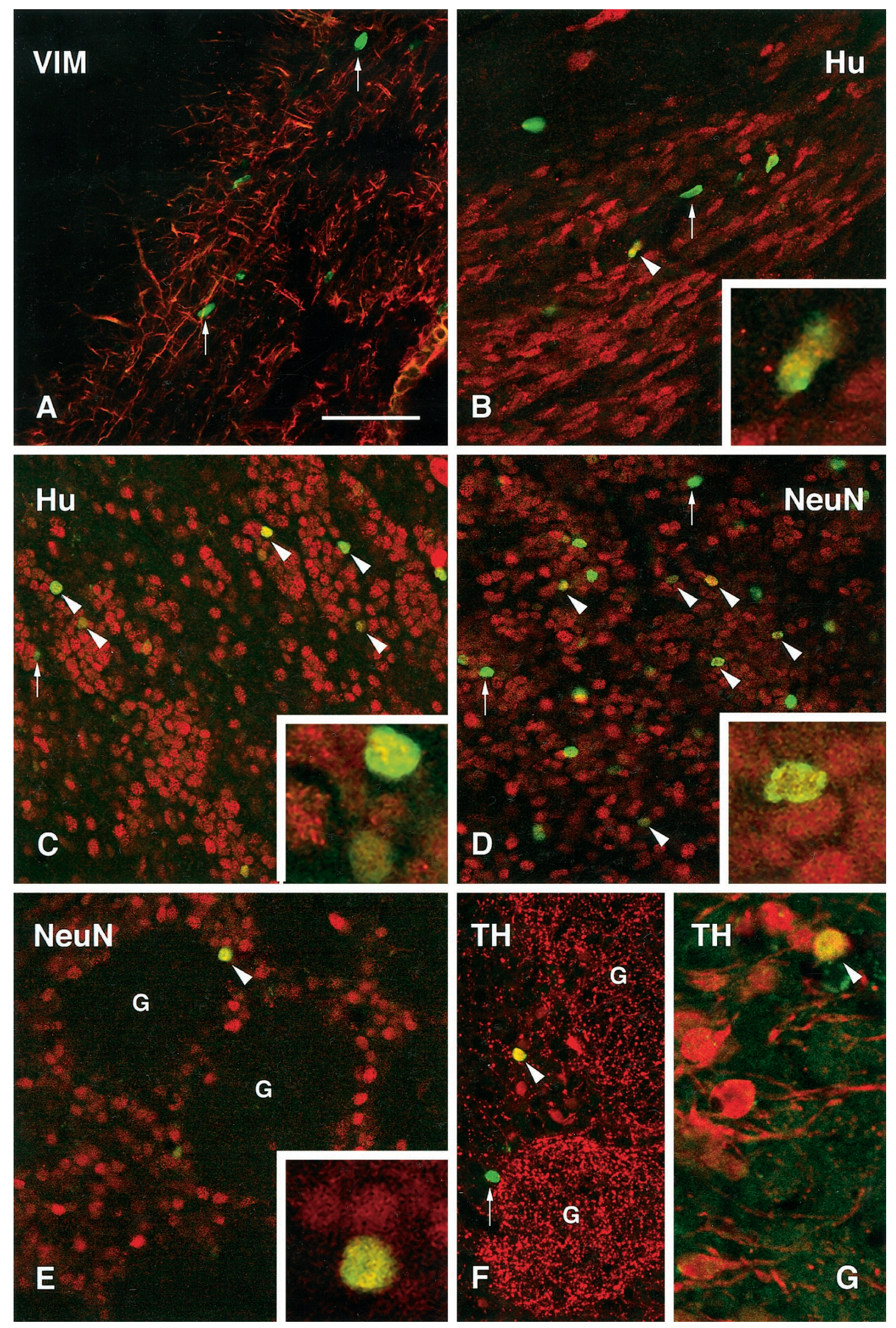

Figure 2. Confocal images of BrdU-labeled ( green) and double-labeled cells (yellow) transplanted in the SVZa at 6 weeks after transplantation. A, Vimentin (VIM) staining delineates the RMS. BrdU-positive cells (arrows) were observed along the RMS but were not VIM positive. B, Many host cells present within the RMS were positively stained with an antibody to $\mathrm{Hu}$, a neuronal phenotypic marker, and some transplanted cells were also Hu positive (arrowhead, enlarged in the inset). C, Many Hu-positive transplanted cells (arrowheads) were located within the granule cell layer of the olfactory bulb. The inset shows two Hu-positive, BrdU-labeled cells (one strongly and one weakly BrdU labeled). $D$, Approximately half of the transplanted cells (arrowheads) were double-labeled with NeuN in both the granule cell layer $(D)$ and the periglomerular layer $(E)$. $G$, Glomerulus. Insets in $D$ and $E$ show double-labeled cells in higher magnification. $F, G$, A small proportion of the BrdU-positive cells found in the periglomerular layer were also TH positive (arrowheads). Scale bar (shown in $A$ ): $A-F, 100 \mu \mathrm{m} ; G, 50 \mu \mathrm{m}$. 
Table 1. The proportion of BrdU-labeled cells, which also express other markers of mature CNS phenotypes, at 6 weeks after transplantation to different regions of the adult rat brain

\begin{tabular}{lcccc}
\multicolumn{5}{c}{ SVZa and RMS transplants } \\
\cline { 2 - 5 } & Graft core & RMS & Granular layer & Periglomerular layer \\
\hline $\mathrm{Hu}$ & 0 & + & ++++ & +++ \\
$\beta$-tubulin-III & 0 & + & - & - \\
NeuN & 0 & 0 & +++ & ++ \\
GAD $_{67}$ & 0 & 0 & +++ & ++ \\
TH $_{\text {DARPP-32 }}$ & 0 & 0 & - & + \\
GFAP & 0 & 0 & 0 & 0 \\
Vimentin & 0 & 0 & 0 & 0 \\
\hline
\end{tabular}

\begin{tabular}{lccccc}
\hline \multicolumn{7}{c}{ Hippocampal transplants } \\
\cline { 2 - 6 } & Graft core & Subgranular layer & Granule cell layer & Hilus & CA3 \\
\hline Hu & ++ & +++++ & ++++ & + & 0 \\
$\beta$-tubulin-III & ++ & +++++ & ++++ & - & 0 \\
NeuN & + & +++++ & ++++ & 0 & 0 \\
GAD & - & 0 & 0 & - & - \\
TH & 0 & 0 & 0 & 0 & 0 \\
DARPP-32 & 0 & 0 & 0 & 0 & 0 \\
Calbindin & + & +++++ & ++++ & 0 & 0 \\
GFAP & ++ & 0 & 0 & ++ & ++ \\
\hline
\end{tabular}

\begin{tabular}{lccc} 
& \multicolumn{2}{c}{ Striatal transplants } & \\
\cline { 2 - 4 } & Graft core & $<0.4 \mathrm{~mm}$ from core & $0.4-1.5 \mathrm{~mm}$ from core \\
\hline $\mathrm{Hu}$ & +++++ & ++++ & 0 \\
$\mathrm{NeuN}$ & 0 & 0 & 0 \\
$\mathrm{GAD}_{67}$ & +++ & ++ & + \\
$\mathrm{TH}$ & 0 & 0 & 0 \\
$\mathrm{DARPP}-32$ & 0 & + & 0 \\
Calbindin & 0 & + & 0 \\
GFAP & ++ & +++ & +++
\end{tabular}

The frequency of double-labeled cells was quite consistent for the different phenotypic markers among the animals used for this analysis: olfactory bulb, $n=8$; hippocampus, $n=10$, striatum, $n=10$. Double-labeling was assessed by confocal microscopy of randomly selected areas in sections stained with a combination of FITC-, Cy2-, and Cy3-labeled antibodies (see Materials and Methods). The data are based on observations from three representative animals in each group. 0, Cells not found; +, 1-10\%; ++, 11-40\%; +++, 41-60\%; ++++, 61-80\%; +++++, >80\%.

\section{The hippocampus}

Transplants of 100,000 cells were placed within the hilar region of the dentate gyrus. At both 2 and 6 weeks after grafting, many of the injected BrdU-positive cells remained as a cluster just below the granule cell layer (Fig. 5A). This position of the cell deposit is characteristic for cells that are implanted by passive injection into the dentate gyrus, because of the presence of a cleavage plane underneath the granule cell layer (Wells et al., 1988). A significant proportion of the BrdU-positive cells, however, had migrated within the subgranular layer of the dentate gyrus and into the granule cell layer itself (Fig. $5 B-F$ ). In addition, some cells were found scattered in the hilus and the molecular layer of the dentate gyrus, as well as in the overlying CA3 region. The extent of cell migration was similar at 2 and 6 weeks. Typically, cells that had migrated longer distances from the transplant core were more weakly labeled with BrdU, suggesting that the migrated cells had undergone further cell divisions.

The BrdU-labeled cells that had integrated into the granular and subgranular layers had the same size and shape as the intrinsic host granule cells, and a large number of them expressed the neuronal markers $\mathrm{Hu}$ (Fig. 5B), NeuN (Fig. 5C), and $\beta$-tubulin-III (Fig. $5 D$ ) at both time points. The calbindin marker that is characteristic for the intrinsic granule cells was clearly present in many of the transplanted cells at 6 weeks but not at 2 weeks after transplantation. Occasional $\mathrm{BrdU} / \mathrm{Hu}$ double-labeled cells, but no BrdU/NeuN or BrdU/calbindin double-labeled cells, were found outside these layers. A large proportion of the transplanted cells within the granule cell layer were calbindin positive (Fig. $5 E$ ). No BrdU/GAD ${ }_{67}$ double-labeled cells were observed in these transplants (Fig. 5F). Similarly, no cells that coexpressed BrdU and DARPP-32 were observed within any region of the hippocampus. BrdU-labeled cells expressing the glial marker GFAP were found in areas outside the dentate gyrus, both in the CA3 area and in areas close to ventricle as well as within or close to the graft core (see Fig. $9 C$ ). The extent of neuronal and glial differentiation of the transplanted cells within each region of the hippocampus is given in Table 1.

Staining with the hTau antibody revealed scattered axonal and cellular profiles, both within the graft core and in individual cells that had migrated away from the initial transplant site within the 

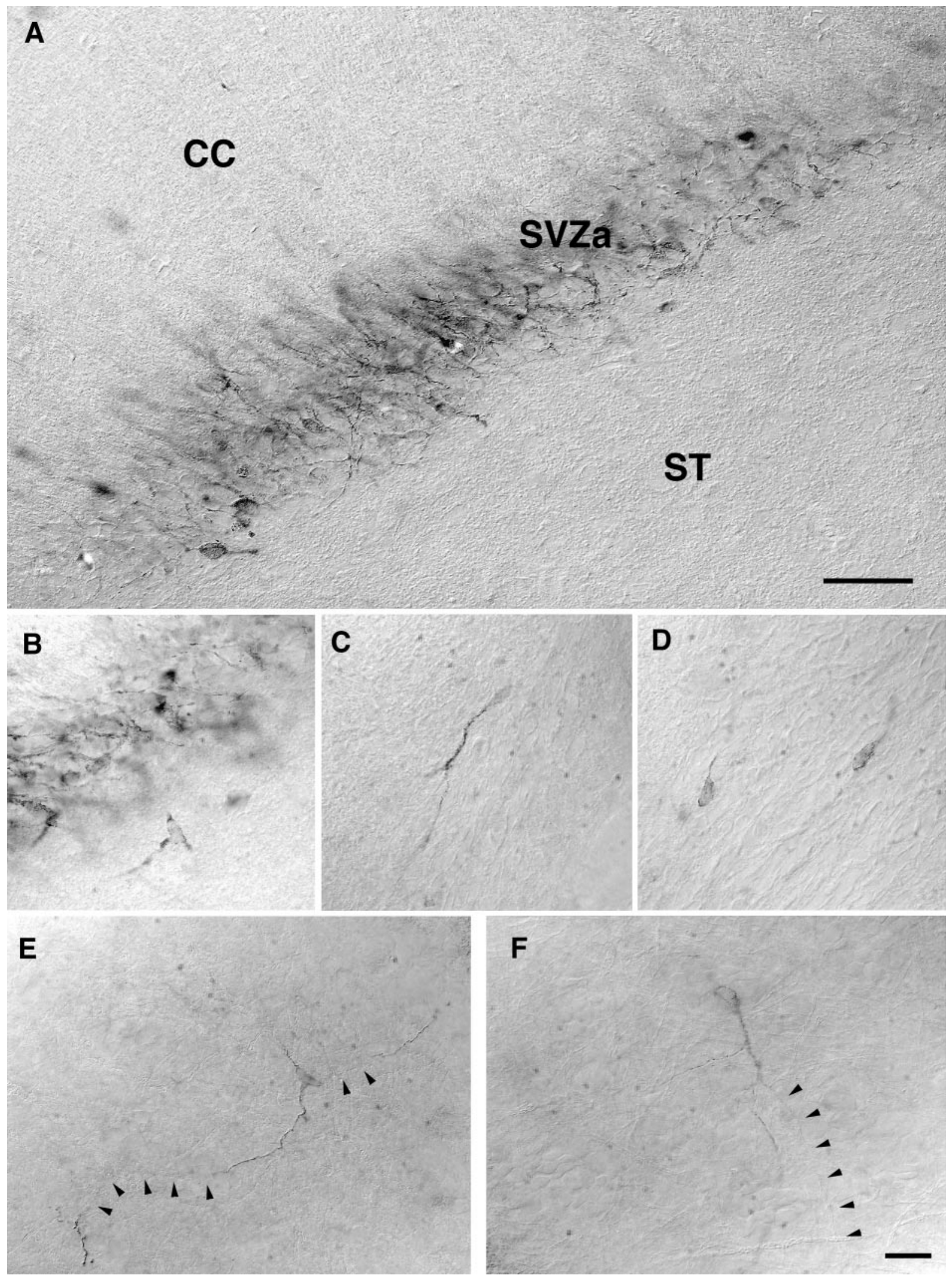

Figure 3. Grafts to the SVZa stained with a human-specific antibody to tau, at 6 weeks after transplantation. $A$, Sagittal section showing neuronal cell bodies and axons located within the SVZa, between the striatum $(S T)$ and the overlying corpus callosum $(C C)$. $B-D$, Higher magnification of individual neuronal profiles at the periphery of the transplant $(B)$ and migrating in the RMS $(C, D) . E$, $F$, Individual cells located deep within the olfactory bulb, showing morphological features of mature neurons. Scale bars: $A, 100 \mu \mathrm{m}$; (shown in $F$ ) $B-F, 10 \mu \mathrm{m}$. 

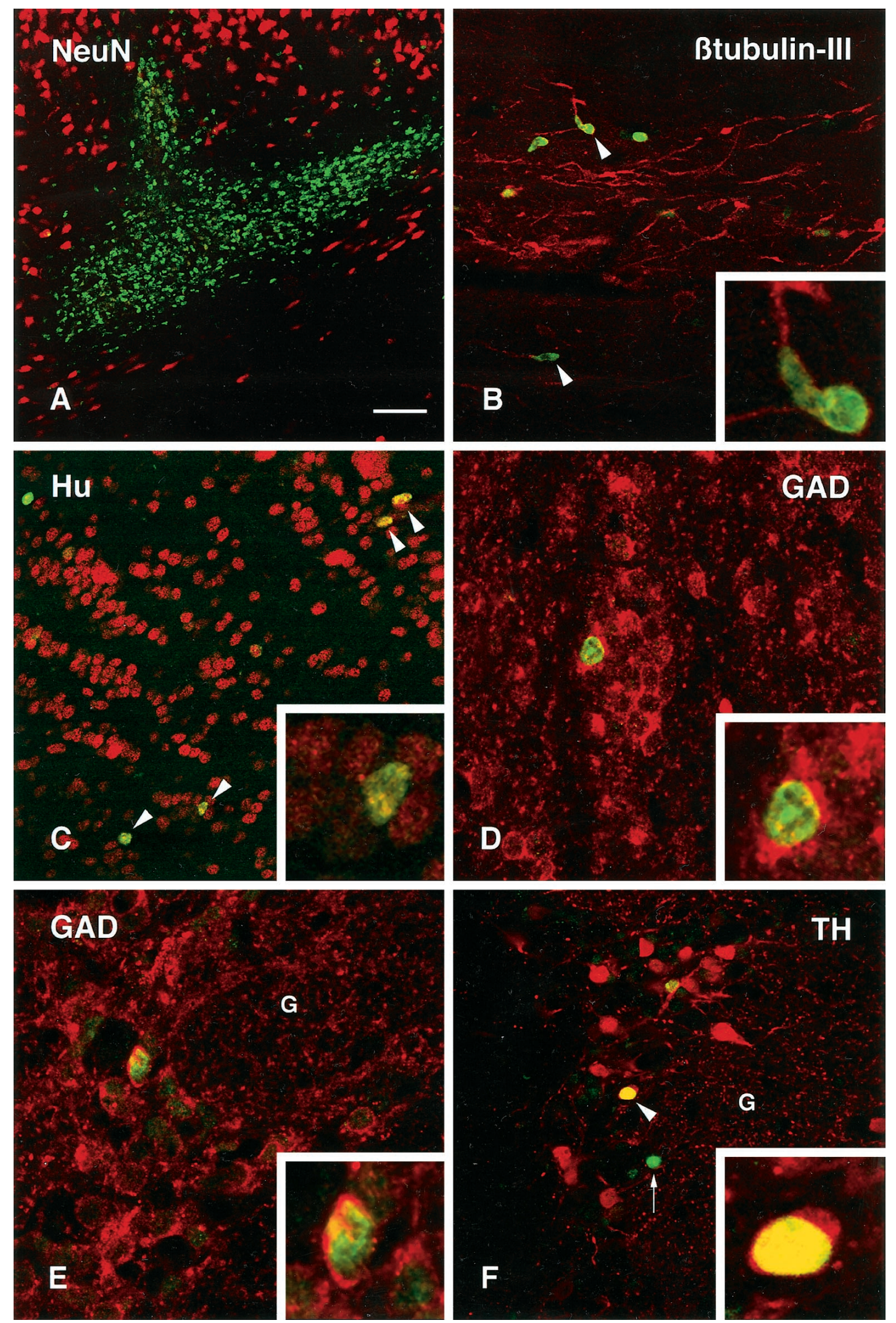

G

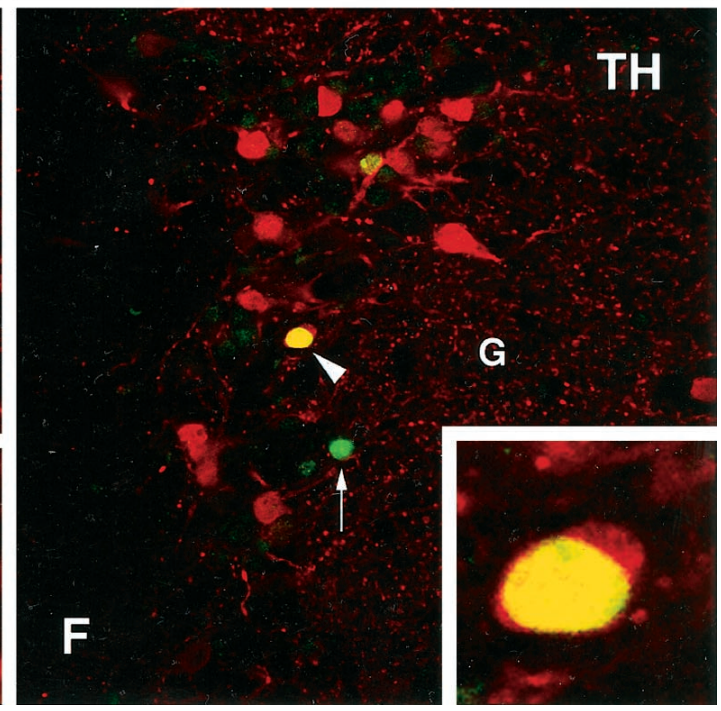

Figure 4. Confocal images of BrdU-labeled (green) and double-labeled cells (yellow) transplanted in the RMS. A, A typical graft at 2 weeks after transplantation, situated in the RMS with only moderate migration of grafted cells in either rostral and caudal direction from the graft core. $B$, At 6 weeks after transplantation cells were seen migrating along the RMS. A small proportion of the transplanted cells were labeled with the early neuronal marker $\beta$-tubulin III (arrowheads). This marker was also present in many of the host cells within this pathway. $C$, Transplanted cells were found scattered throughout the olfactory bulb. Many of them were Hu positive (arrowheads), indicating their differentiation to a neuronal phenotype. $D$, Within the granule cell layer many of the BrdU-labeled cells were $\mathrm{GAD}_{67}$ positive. Within the periglomerular layer, BrdU-positive cells stained positively for either $\mathrm{GAD}_{67}(E)$ or TH $(F)$. Insets show individual double-labeled cells in higher magnification. Arrow in $F$ marks a TH-negative transplanted cell. Scale bar (shown in $A$ ): $A, 150 \mu \mathrm{m} ; B, C, 50 \mu \mathrm{m} ; D-F, 25 \mu \mathrm{m}$. 

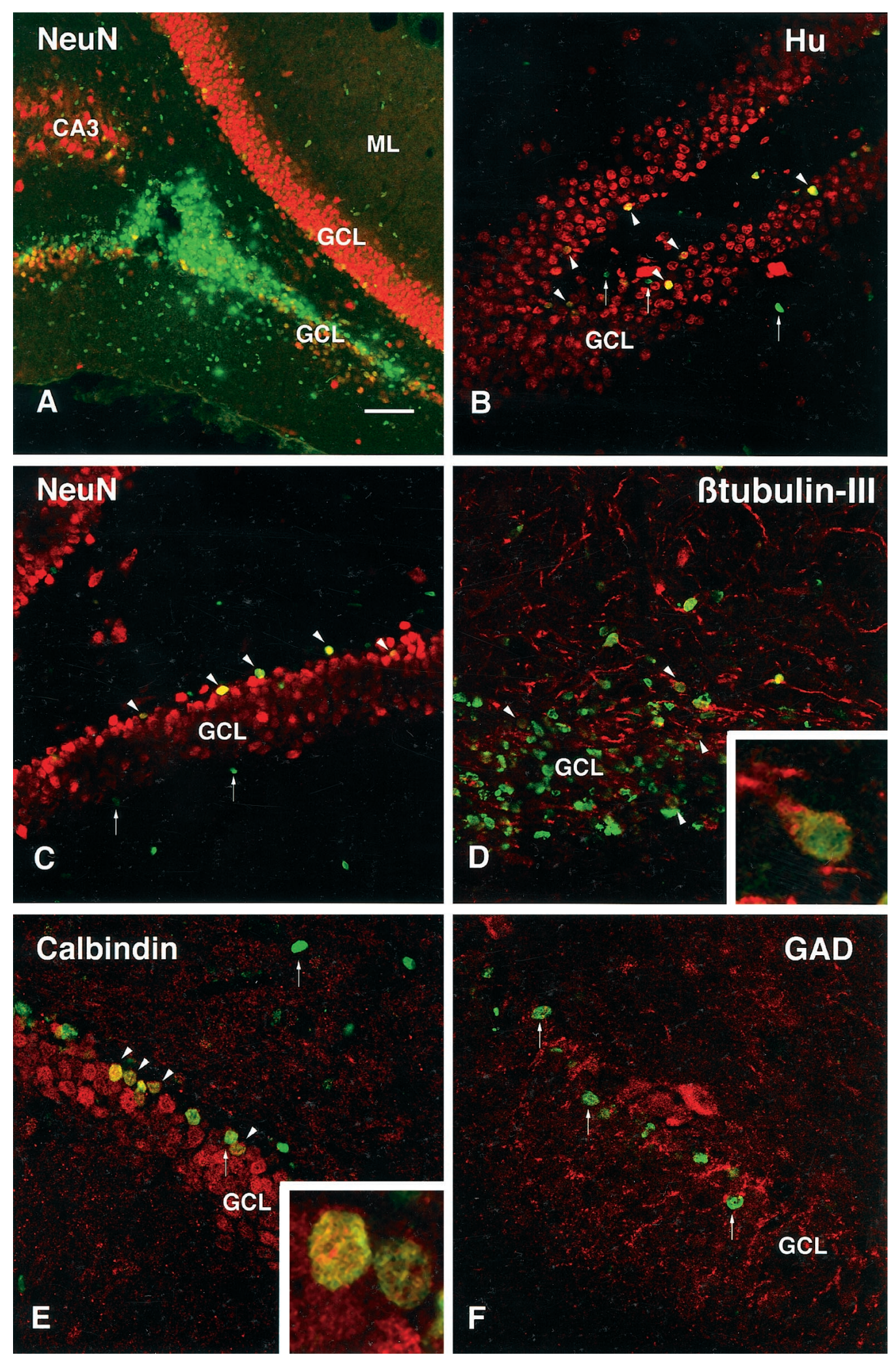

Figure 5. Confocal images of BrdU-labeled ( green) and double-labeled cells ( yellow) transplanted in the hippocampus. $A$, The core of transplanted cells was located within either the dorsal or ventral blades of the granule cell layer $(G C L)$ in the dentate gyrus. $B, C$, By 2 weeks after transplantation, Huand NeuN-positive BrdU-labeled cells were observed at some distance from the graft core, mainly in the subgranular layer and also within the granule cell layer (arrowheads). D, BrdU-labeled transplanted cells positive for the neuronal marker $\beta$-tubulin-III (arrowheads) were found both within the graft core and in cells that had migrated along the subgranular layer. $E$, At 6 weeks (but not at 2 weeks) after transplantation, calbindin-positive cells were observed in the granule cell layer (arrowheads). $F$, No GAD 67 -positive interneurons were observed. Insets show an individual $\beta$-tubulin-III/BrdU-labeled cell in the cluster of grafted cells in the subgranular layer in $D$, and two calbindin/BrdU-labeled cells within the deep part of the granule cell layer. Arrows indicate single-labeled BrdU-positive cells. Scale bar (shown in $A$ ): $A, 150 \mu \mathrm{m} ; B, C, 75 \mu \mathrm{m} ; D-F, 50 \mu \mathrm{m}$. $C A 3$, CA3 region of hippocampus; $M L$, molecular layer; $G C L$, granule cell layer. 

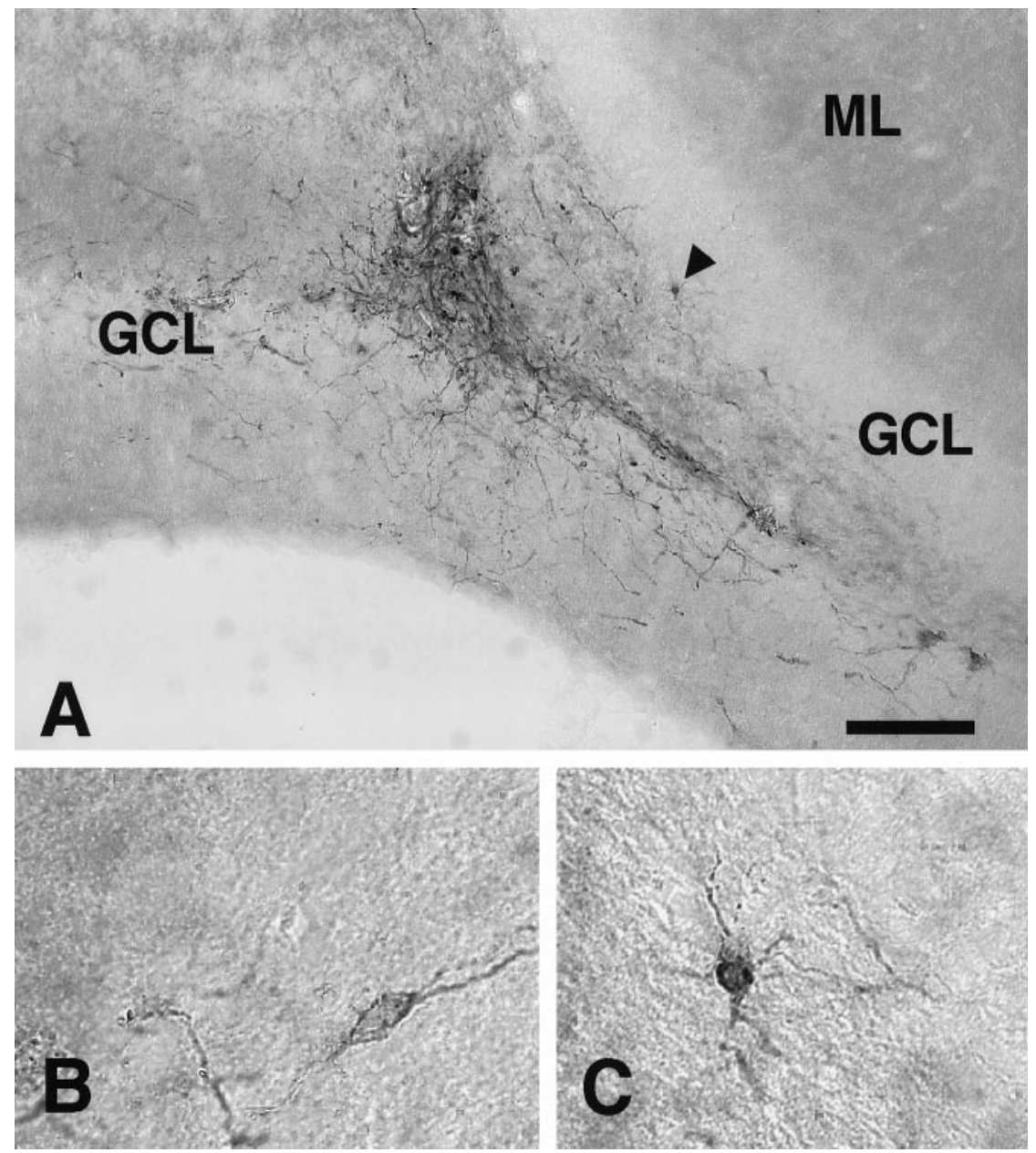

Figure 6. Hippocampal transplants stained with the hTau antibody. $A$, A transplant in the dentate gyrus at 6 weeks after transplantation. $B$, A tau-positive cell with a typically immature neuronal profile with one primary process. $C$, A more differentiated tau-positive neuron with more complex processes, situated within the subgranular layer (arrowhead in $A$ ). Scale bar (shown in $A$ ): $A, 150 \mu \mathrm{m} ; B, C, 30 \mu \mathrm{m}$. $M L$, Molecular layer; $G C L$, granule cell layer; $H$, hilus. granular and subgranular cell layers (Fig. 6A). At 2 weeks the cells appeared fairly immature, with a few short Tau-positive processes. At 6 weeks, cells with morphological features of neurons with processes were observed (Fig. 6B,C). Tau-positive cells were also seen in the hilus and molecular layer and along the needle tract.

\section{The striatum}

The transplants were placed centrally within the head of the caudate-putamen. At both 2 and 6 weeks after grafting, the grafted cells were found as a BrdU-labeled cell cluster at the site of implantation. Many of the BrdU-labeled cells, however, were observed to have migrated into the surrounding host striatum, without any preferential direction, to a distance of $\sim 1-1.5 \mathrm{~mm}$ from the graft core (Fig. $7 A$ ). The size of individual BrdU nuclei varied considerably, both within the graft core and in cells that were located in the adjacent host striatum $(<0.4 \mathrm{~mm}$ from the graft core). All of the cells that had migrated over longer distances were of small size and more faintly labeled, suggesting a dilution of the BrdU label caused by cell division. In sagittal sections the BrdU-positive cells could be seen to be aligned with the gray matter, interspersed with the fibers of the internal capsule.

Double-staining revealed that the majority of the BrdUpositive cells in the graft core and in the adjacent host striatum were double-labeled for the early neuronal marker Hu (Fig. 7B) but negative for $\mathrm{NeuN}$ (Fig. 7C). Many BrdU/Hu double-labeled cells occurred also at the graft-host border and within the adja- cent host striatum, up to a distance of $\sim 0.3-0.4 \mathrm{~mm}$ from the graft core. Although the majority of the Hu-positive cells within the graft core were small in size and round or oval in shape, similar to the Hu-positive cells within the SVZ of the host brain, a substantial proportion of the BrdU/Hu-positive cells at the graft-host border and in the host striatum were larger in size (10-15 $\mu \mathrm{m})$, i.e., in the range of the Hu-positive neurons within the host striatum. None of the cells expressed NeuN, which is also the case, however, for most of the host striatal neurons. All BrdU-labeled cells located farther away from the graft core were $\mathrm{Hu}$ negative. These cells were all of small size and often found in satellite positions, closely apposed to host striatal neurons (Fig. $7 C$, arrows) or close to blood vessels. The location and staining properties of these small-sized cells suggest that they had differentiated, at least in part, into glia. Colocalization of BrdU and the astrocyte marker GFAP was unequivocally demonstrated at the graft-host border, i.e., within the area of GFAP-positive reactive astrocytes surrounding the graft core (see Fig. 9D, inset).

The neuronal phenotype of the transplanted cells was further investigated using antibodies against the GABA-synthesizing enzyme $\mathrm{GAD}_{67}$, which is present in the vast majority $(>90 \%)$ of the neurons within the striatum; DARPP-32, which is a marker for the medium-sized spiny striatal projection neurons; and calbindin, which is normally present in the medium spiny projection neurons in the matrix component of the striatum (for review, see Gerfen, 1992). BrdU/GAD ${ }_{67}$ double-labeled cells were observed both in the transplant core and within the host striatum at the 

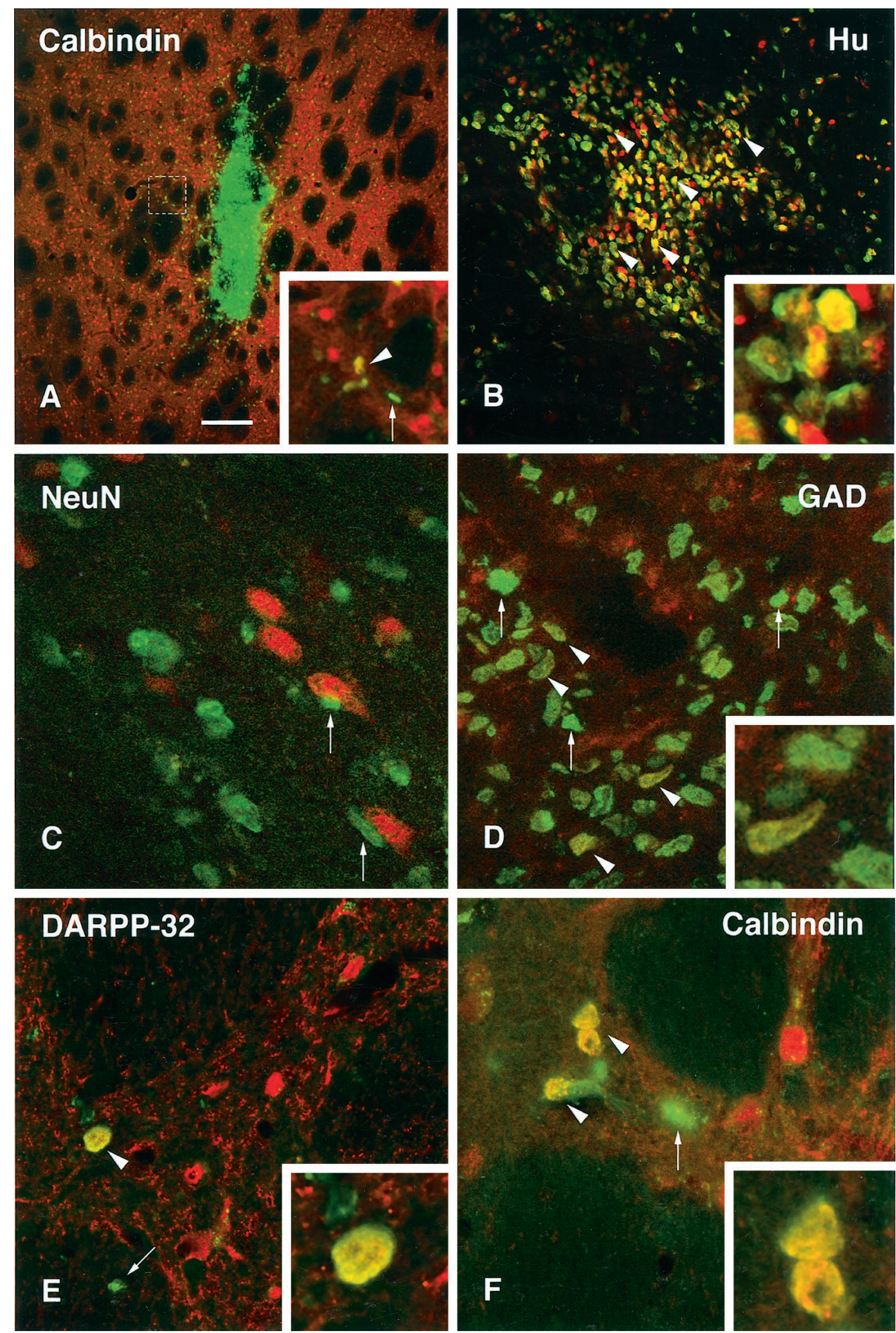

Figure 7. Confocal images of BrdU-labeled ( green) and double-labeled cells ( yellow) transplanted in the striatum. A, Coronal section through the graft core at 6 weeks after transplantation, showing a dense cluster of cells at the injection site and migration of BrdU-labeled cells away from the graft core, in both gray and white matter. Inset shows region in box at higher magnification, also illustrated in $F$. $B$, Many of the transplanted cells were positively stained with $\mathrm{Hu}(\mathrm{red})$, even within the graft core (arrowheads, enlarged in the inset). $C$, No BrdU/NeuN double-labeled cells were found in the graft core or among those cells that had migrated into the host striatum. Arrows indicate transplanted cells that were found in close association with NeuN-positive host neurons $(\mathrm{red})$. $D$, A number of transplanted cells were positive for the enzyme $\mathrm{GAD}_{67}$ in the periphery of the graft core (arrowheads). One of the double-labeled cells is shown at higher magnification in the inset. E, BrdU/DARPP-32 double-labeled cells were occasionally observed (arrowhead and inset at higher magnification). These were generally faintly labeled and found only in the immediate vicinity of the transplant core. $F$, Similarly, $\mathrm{BrdU} / \mathrm{Calbindin}$ double-labeled cells were found both in the periphery of the graft and in adjacent regions of the host striatum. Scale bar (shown in $A$ ): $A, 300 \mu \mathrm{m} ; B, 150 \mu \mathrm{m} ; D-F, 25 \mu \mathrm{m}$. 

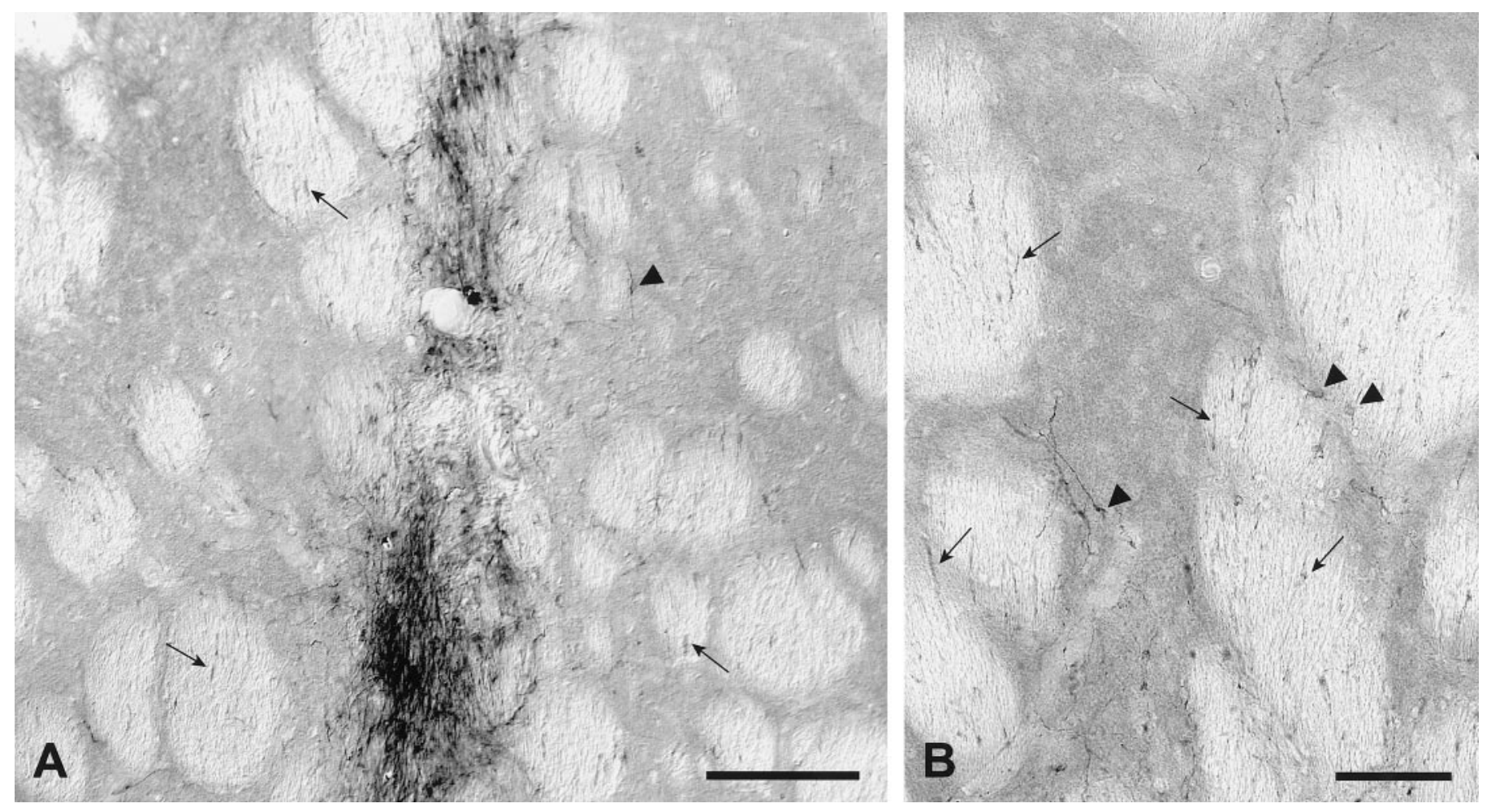

Figure 8. Striatal transplants stained with the hTau antibody. Six weeks after transplantation, coronal sections revealed tau-positive neuronal profiles densely packed within the graft core $(A)$. Individual cells with neuronal profiles were observed also in the host striatum adjacent to the graft (arrowheads in $A$ and $B$ ). Axonal processes were seen to extend caudally within the white matter bundles of the internal capsule (arrows in $A$ and $B)$. Scale bars: $A$, $500 \mu \mathrm{m} ; B, 100 \mu \mathrm{m}$.

periphery of the transplants (Fig. 7D). In addition, some BrdUlabeled cells expressed calbindin (Fig. $7 A, F$, inset) and occasionally also DARPP-32. These cells were located at the periphery of the transplants and in the adjacent host striatum up to a distance of $\sim 0.3-0.4 \mathrm{~mm}$ from the graft-host border and were similar in size and shape to those present within the host striatum. The BrdU/DARPP-32 double-labeled cells were only weakly DARPP-32 positive but were comparable in size to the host DARPP-32-positive neurons (Fig. 7E). None of the transplanted cells expressed TH, either within the graft core or within the host striatum. Table 1 outlines the extent of expression of neuronal and glial markers at different distances from the graft core.

Staining with the hTau antibody revealed a graft core of clustered tau-positive cells and fibers (Fig. $8 A$ ). In sagittal sections, loose bundles of tau-positive fibers were seen to leave the graft core in both the rostral and caudal direction, along the white matter bundles of the internal capsule. In cross section, these fibers were found primarily within the white matter bundles (Fig. $8 B$, arrows). Individual cells were also observed at some distance from the graft core (Fig. $8 A, B$, arrowheads). In these cases, the cell bodies were often located within the gray matter, with their processes projecting into the white matter tracts. At 6 weeks, tau-positive axons could be traced caudally from the graft core within the internal capsule bundles for a distance of $\sim 1-2 \mathrm{~mm}$; some of these fibers were seen to enter the globus pallidus, and in some cases scattered tau-positive fibers could be traced as far as the entopeduncular nucleus.

\section{DISCUSSION}

These present results show that the long-term propagated human neurosphere cultures contained progenitors that can respond in vivo to cues present in both neurogenic and non-neurogenic regions of the adult rat brain. The expression of phenotypic markers provided evidence for site-specific neural differentiation within each of the three grafted regions. In the olfactory bulb the cells that integrated into the granular and periglomerular layers expressed NeuN, TH, and $\mathrm{GAD}_{67}$, similar to the dopaminergic and GABAergic cells normally present in these regions. In the dentate gyrus some of the cells assumed a position, morphology, and phenotype similar to the NeuN/calbindin-positive granule cells within the granule cell layer. And in the striatum, cells located in the periphery of the transplants expressed $\mathrm{GAD}_{67}$ and calbindin as well as low levels of the striatum-specific marker DARPP-32.

A combination of EGF, bFGF, and LIF was used to expand the human progenitors. It has been shown previously that EGF and bFGF act cooperatively in promoting the proliferation of rat and human neural progenitors (Vescovi et al., 1993; Weiss et al., 1996a; Svendsen et al., 1997). bFGF appears to be a mitogen for both unipotent and multipotent neuronal and glial progenitors (Murphy et al., 1990; Vescovi et al., 1993; Ray and Gage, 1994; Kilpatrick and Bartlett, 1995; Palmer et al., 1995) and may act broadly to maintain neural progenitor cells as a constitutively proliferating population in vitro (Palmer et al., 1995). It seems likely, therefore, that the combination of growth factors used here served to maintain both multipotent and lineage-restricted progenitors in continuous cell cycle and that the ability to migrate and integrate into the adult host brain was expressed by specific subsets of cells. Previous studies suggest that the in vivo properties of in vitro expanded neural progenitors may differ depending on the growth factors used. Rat or mouse neurosphere cells ex- 

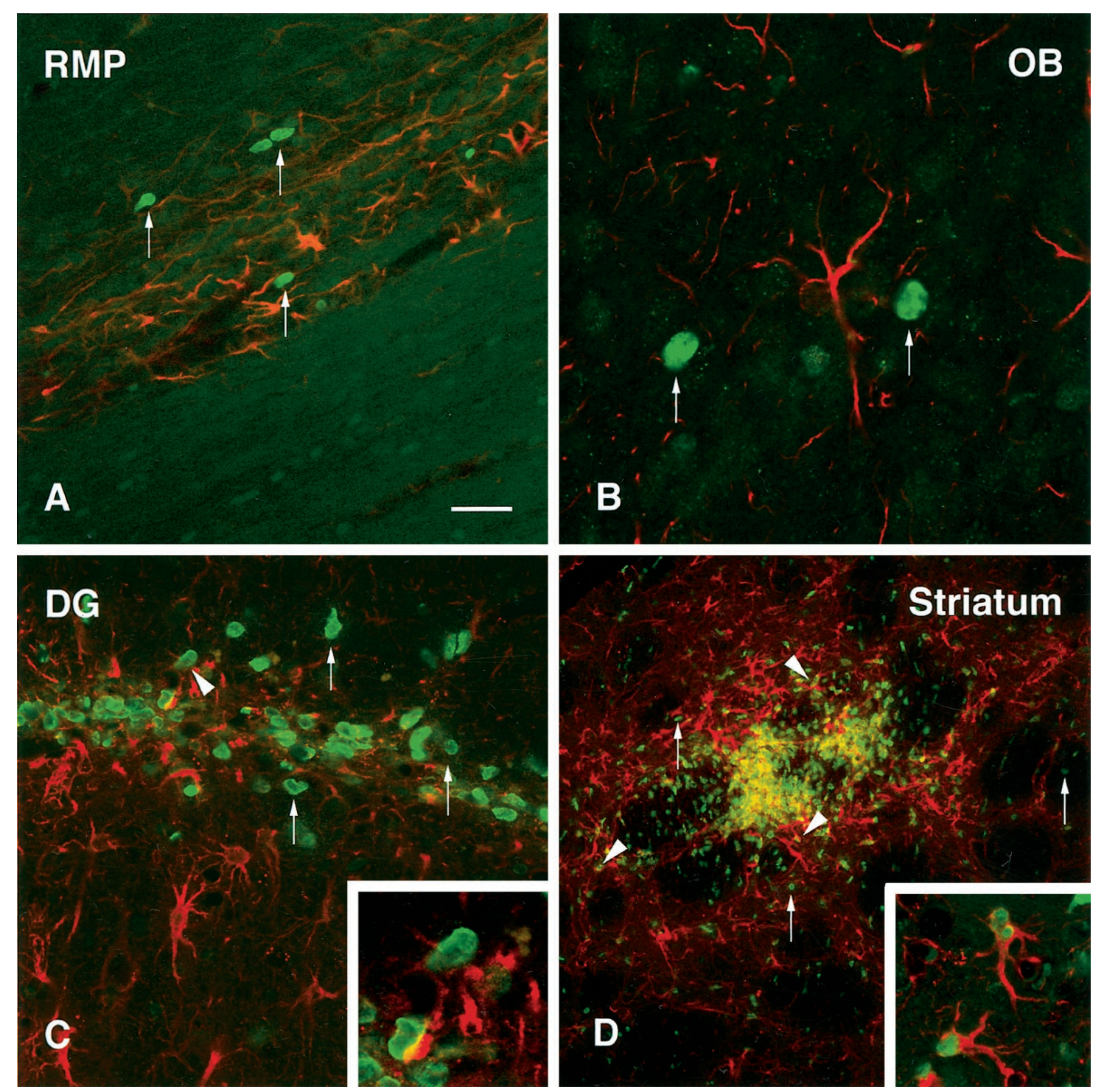

Figure 9. GFAP was used to label astrocytes within the graft areas (red) to assess the extent of colocalization with BrdU-labeled transplanted cells ( green). A, Cells within the RMS at 6 weeks after transplantation were often closely associated with GFAP profiles, although no double-labeled cells were observed (arrows). B, Within the granule cell layer of the olfactory bulb, BrdU-positive cells were interspersed with, but not colocalized with, GFAP (arrows). $C$, In the dentate gyrus, cells within the transplant core were occasionally closely associated with GFAP-positive cytoplasmic staining, possibly indicating a double-labeled cell. $D$, Staining within the striatum revealed a dense network of GFAP-positive processes (red) intermingled with the BrdU-positive cells ( green). Many clear examples of double-labeled cells were observed (arrowheads), although examples of BrdU single-labeled cells were also frequently observed (arrows). Insets show BrdU/GFAP double-labeled cells at higher magnification. Scale bar (shown in $A$ ): $A$, $C$, $50 \mu$ m; $B$, $25 \mu \mathrm{m} ; D, 150 \mu \mathrm{m}$.

panded in the presence of EGF alone have generated only glial cells and no neurons after transplantation to the developing rat forebrain (Winkler et al., 1998) or adult rat spinal cord (Hammang et al., 1997), and they exhibit poor survival and integration after transplantation to the striatum (Svendsen et al., 1996; C. Winkler, R. A. Fricker, A. Björklund, unpublished observations). By contrast, adult rat hippocampal progenitors cultured in the presence of bFGF exhibit both migration and neurogenesis after transplantation in the adult rat brain (Gage et al., 1995; Suhonen et al., 1996).

\section{Site-specific differentiation of the grafted cells}

In the SVZa, which is one of the two sites where neurogenesis continues into adulthood in the mammalian CNS, the endogenous neuronal progenitors have been shown to migrate along the
RMS and reach the bulb within 2-15 d after their generation in the SVZa (Lois and Alvarez-Buylla, 1994). The cells are already committed to a neuronal phenotype while in the migratory path, although they continue to divide during migration (Menezes et al., 1995). The cells generated by SVZa postnatally are interneurons, above all GABAergic and dopaminergic interneurons in the granular and periglomerular layers of the olfactory bulb (Luskin, 1993; Lois and Alvarez-Buylla, 1994; Betarbet et al., 1996).

The transplanted human neural progenitor cells expressed the early neuronal markers $\mathrm{Hu}$ and $\beta$-tubulin-III during migration to the olfactory bulb, indicating that some of the transplanted progenitors were committed to a neuronal fate already in the SVZ, similar to the endogenous neuronal progenitors generated in the SVZa (Lois and Alvarez-Buylla, 1994; Menezes et al., 1995). On 
reaching the bulb, BrdU-positive cells distributed in the granular and periglomerular layers and coexpressed neuronal markers such as $\mathrm{Hu}$ and $\mathrm{NeuN}$, as well as hTau. This is in agreement with previous results obtained with rat or mouse SVZa progenitors (Luskin, 1993; Lois and Alvarez-Buylla, 1994) and a recent study using transplantation of human neural stem cells (Flax et al., 1998). One interesting difference between the transplanted human cells in the current study and endogenous SVZa progenitors is the time course of migration: few of the transplanted human progenitors had entered the RMS at 2 weeks, and many still remained dispersed along the RMS by 6 weeks. One reason for this may be a species difference. Transplants of human primary cells show a more protracted development than rat-to-rat grafts, which suggests that the human cells retain some type of internal developmental clock for their differentiation and maturation (Grasbon-Frodl et al., 1996, 1997). Indeed, Suhonen et al. (1996) reported that adult rat neural progenitors transplanted to the SVZa in adult rats are distributed along the entire length of the RMS by 1 week, and by 8 weeks $\sim 90 \%$ of the cells had reached the bulb. Similarly, Lois and Alvarez-Buylla (1994) observed that SVZa progenitors, implanted into the adult SVZa, reach the bulb within $30 \mathrm{~d}$ after transplantation. These observations indicate that the slow onset and protracted time course of migration of the human cells reflect intrinsic developmental constraints.

In hippocampus the transplanted cells distributed along the subgranular and granular layers of the dentate gyrus. Although cells were observed also in other layers of the dentate and the CA3 region, cells expressing neuronal markers occurred only within the subgranular or granular layers, suggesting that the human progenitors, similar to rat hippocampal and cerebellar progenitors (Gage et al., 1995; Vicario-Abejon et al., 1995), are able to respond to local cues specifically localized in these layers. The transition zone between the hilus and the granule cell layer is the site where endogenous neuronal progenitors are normally generated (Altman and Das, 1966; Altman and Bayer, 1990), providing a source of new granule cells throughout life (Kaplan and Hinds, 1977; Cameron et al., 1993; Kuhn et al., 1996). As judged by morphological criteria, i.e., size, shape, and distribution of the cells, and expression of characteristic neuronal markers, the grafted progenitors are induced by local signals to express neuronal features similar to the resident granule cells. It remains to be demonstrated, however, to what extent these newly formed neurons can undergo complete maturation and establish appropriate axonal and dendritic connectivity.

\section{Cells grafted to the striatum generate both neurons and glia}

Expression of neuronal markers in the striatal transplants indicate that a substantial fraction of the grafted human progenitors had developed toward a neuronal phenotype. Many of the $\mathrm{Hu}-$ positive cells within the transplant core were small and round or oval in shape, similar to the neuronal precursors normally present in the proliferative subependyma in the adult brain. These cells did not express any of the more mature neuronal markers and therefore may be classified as poorly differentiated neuronal precursors. The $\mathrm{GAD}_{67^{-}}$, calbindin-, and DARPP-32-positive cells were exclusively located at the graft-host border and within the adjacent host striatum, up to a distance of $\sim 0.3-0.4 \mathrm{~mm}$. The size and shape of these cells were similar to the medium-sized neurons of the host striatum. Many of these are GABAergic and stain positively for $\mathrm{GAD}_{67}$; one subclass, the striatal projection neu- rons, is further characterized by the expression of calbindin and/or DARPP-32.

These data indicate that the human neural progenitors can undergo neurogenesis also in the the normally non-neurogenic environment of the adult striatum and assume neuronal phenotype(s) similar to those normally present here but that in the absence of suitable substrates for migration they remain close to the implantation site. Interestingly, in sections stained with the hTau antibody some of these newly formed neurons were seen to extend long axon-like processes that could be traced along the fascicles of the internal capsule to the globus pallidus and in some cases also the entopeduncular nucleus, a distance of $\sim 2 \mathrm{~mm}$.

The cells that migrated over longer distances within the adult striatum were all $\mathrm{Hu}$ negative and of small size. Many of them were found in satellite position to the medium-sized host striatal neurons or close to blood vessels, suggesting that they had assumed a glial-like phenotype (Fig. 9). A migratory capacity of immature glia (or glial precursors) within the adult CNS has been reported for both astrocytes and oligodendrocytes by several investigators (Blakemore and Franklin, 1991). Extensive astrocyte migration within the adult striatum, similar in extent to the one observed here, has previously been described in transplants of human neuronal progenitors (Svendsen et al., 1997) and freshly dissociated human embryonic striatal and diencephalic tissue (Pundt et al., 1995). In these cases the migratory cells appear to be glial precursors in a proliferative, migratory stage of their development. Consistent with this, we observed that cells located at progressively greater distances from the transplant core had lower levels of BrdU labeling than the cells that remained at the implantation site, suggesting that the migrating cells continued to divide as they dispersed within the host striatal parenchyma.

\section{Implications for brain repair}

The human neurosphere cultures are particularly suitable for transplantation in that they can be harvested and implanted without dissociation and detachment from a culture substrate. The cultures used here had been expanded up to 10 million-fold, which means that each transplant of 100,000-200,000 cells in theory could be derived from a single cell in the original cell preparation. Because the in vivo properties of the cells were indistinguishable over a wide range of passages (from 9 to 21), the present culture system could provide an almost unlimited source of human neural progenitor cells for transplantation.

The present results show that subpopulations of cells contained within the human neurosphere cultures can respond appropriately to specific extracellular cues present in each of the four target regions in the adult rat brain. Because the human neurosphere cultures are likely to contain a mixture of multipotent and lineage-restricted progenitors, the specific migratory patterns seen in the different locations may be explained either by the ability of an undifferentiated stem cell-like cell to differentiate along alternative neuronal or glial pathways in response to diverse local cues, or alternatively, by the presence of different subpopulations of lineage-restricted neuronal or glial precursors that were already committed to specific neuronal or glial fates. The present data seem compatible with both alternatives.

In conclusion, the long-term propagated human neural progenitors described here demonstrate a remarkable capacity for migration, integration, and site-specific differentiation in the adult brain. The growth factor combination used here acted to maintain the progenitors as a constitutively proliferating cell popula- 
tion without losing their capacity to respond to those extracellular cues normally present in the adult CNS. With further refinement of the procedure, e.g., by application of cell enrichment and cell sorting techniques, this culture system may provide an almost unlimited source of human neural progenitors at different stages of differentiation and lineage restriction. Such cells will be of great interest both as an experimental tool and as an alternative to primary embryonic brain tissue for intracerebral transplantation.

\section{REFERENCES}

Altman J, Bayer SA (1990) Migration and distribution of two populations of hippocampal granule cell precursors during the perinatal and postnatal periods. J Comp Neurol 124:319-335.

Altman J, Das GD (1966) Autoradiographic and histological studies of postnatal rat neurogenesis. I. A longitudinal investigation of the kinetics, migration and transformation of cells incorporating tritiated thymidine in rats, with special reference to postnatal neurogenesis in some brain regions. J Comp Neurol 126:337-389.

Alvarez-Buylla A (1997) Neurogenesis in the adult brain: prospects for brain repair. In: Isolation, characterization and utilization of CNS stem cells (Gage FH, Christen Y, eds), pp 87-100. New York: Springer.

Barami K, Iversen K, Furneaux H, Goldman SA (1995) Hu protein as an early marker of neuronal phenotypic differentiation by subependymal zone cells of the adult songbird forebrain. J Neurobiol 28:82-101.

Betarbet R, Zigova T, Bakay RA, Luskin MB (1996) Dopamine and GABAergic interneurons of the olfactory bulb are derived from the neonatal subventricular zone. Int J Dev Neurosci 14:921-930.

Blakemore WF, Franklin RJM (1991) Transplantation of glial cells into the CNS. Trends Neurosci 14:323-327.

Brüstle O, Maskos U, McKay RDG (1995) Host-guided migration allows targeted introduction of neurons into the embryonic brain. Neuron 15:1275-1285.

Cameron HA, Wooley CS, McEwen BS, Gould E (1993) Differentiation of newly born neurons and glia in the dentate gyrus of the adult rat. Neuroscience 56:337-344.

Campbell K, Olsson M, Björklund A (1995) Regional incorporation and site-specific differentiation of striatal precursors transplanted to the embryonic forebrain ventricle. Neuron 15:1259-1273.

Carpenter MK, Cui X, Hu Z, Jackson J, Sherman S, Seiger A, Wahlberg L (1999) In vitro expansion of a multipotent population of human neural progenitor cells. Exp Neurol, in press.

Dunnett SB, Bjorklund A (1994) Functional neural transplantation. New York: Raven.

Fishell G (1995) (1995) Striatal precursors adopt cortical identities in response to local cues. Development 121:803-812.

Flax JD, Aurora S, Yang C, Simonin C, Wills AM, Billinghurst LL, Jendoubi M, Sidman RL, Wolfe JH, Kim SU, Snyder EY (1998) Engraftable human neural stem cells respond to developmental cues, replace neurons and express foreign genes. Nat Biotechnol 16:1033-1039.

Gage FH, Coates PW, Palmer TD, Kuhn HG, Fisher LJ, Suhonen JO, Peterson DA, Suhr ST, Ray J (1995) Survival and differentiation of adult neural progenitor cells transplanted to the adult brain. Proc Natl Acad Sci USA 92:11879-11883.

Gao W-Q, Hatten ME (1994) Immortalizing oncogenes subvert the establishment of granule cell identity in developing cerebellum. Development 120:1059-1070.

Gerfen CR (1992) The neostriatal mosaic: multiple levels of compartmental organisation. Trends Neurosci 15:133-139.

Grasbon-Frodl EM, Nakao N, Lindvall O, Brundin P (1996) Phenotypic development of the human embryonic striatal primordium: a study of cultured and grafted neurons from the lateral and medial ganglionic eminences. Neuroscience 73:171-183.

Grasbon-Frodl EM, Nakao N, Lindvall O, Brundin P (1997) Developmental features of human striatal tissue transplanted in a rat model of Huntington's Disease. Neurobiol Dis 3:299-311.

Hammang JP, Archer DR, Duncan ID (1997) Myelination following transplantation of EGF-responsive neural stem cells in a myelin deficient environment. Exp Neurol 147:84-95.
Kaplan MS, Hinds JW (1977) Neurogenesis in the adult rat: electron microscopic analysis of light radioautographs. Science 197:1092-1094.

Kilpatrick TJ, Bartlett PF (1995) Cloned multipotential precursors from the mouse cerebrum require FGF-2, whereas glial restricted precursors are stimulated with either FGF-2 or EGF. J Neurosci 15:3653-3661.

Kuhn HG, Dickinson-Anson H, Gage FH (1996) Neurogenesis in the dentate gyrus of the adult rat: age-related decrease of neuronal progenitor proliferation. J Neurosci 16:2027-2033.

Lois C, Alvarez-Buylla A (1993) Proliferating subventricular zone cells in the adult mammalian forebrain can differentiate into neurons and glia. Proc Natl Acad Sci USA 90:2074-2077.

Lois C, Alvarez-Buylla A (1994) Long-distance neuronal migration in the adult mammalian brain. Science 264:1145-1148.

Luskin MB (1993) Restricted proliferation and migration of postnatally generated neurons derived from the forebrain subventricular zone. Neuron 11:173-189.

Luskin MB, Zigova T, Betarbet R, Soteres BJ (1997) Characterization of neuronal progenitor cells of the neonatal forebrain: In: Isolation, characterization and utilization of CNS stem cells (Gage FH, Christen Y, eds), pp 67-86. New York: Springer.

McConnell S (1988) Development and decision making in the mammalian cerebral cortex. Brain Res 472:1-23.

Menezes JR, Smith CM, Nelson KC, Luskin MB (1995) The division of neuronal progenitors during migration in the neonatal mammalian forebrain. Mol Cell Neurosci 6:496-508.

Murphy M, Drago J, Bartlett PF (1990) Fibroblast growth factor stimulates the proliferation of neural precursor cells in vitro. J Neurosci 25:463-473.

Palmer TD, Ray J, Gage FH (1995) FGF-2-responsive progenitors reside in proliferative and quiescent regions of the adult rodent brain. Mol Cell Neurosci 6:474-486.

Pundt LL, Kondoh T, Low WC (1995) The fate of human glial cells following transplantation in normal rodents and rodent models of neurodegenerative disease. Brain Res 695:25-36.

Ray J, Gage FH (1994) Spinal cord neuroblasts proliferate in response to basic fibroblast growth factor. J Neurosci 14:3548-3564.

Ray J, Peterson DA, Schistine M, Gage FH (1993) Proliferation, differentiation and long-term culture of primary hippocampal neurons. Proc Natl Acad Sci USA 90:3602-3606.

Ray J, Palmer TD, Suhonen J, Takahashi J, Gage FH (1997) Neurogenesis in the adult brain: lessons learned from the studies of progenitor cells from the embryonic and adult central nervous systems. In: Isolation, characterization and utilization of CNS stem cells (Gage FH, Christen Y, eds), pp 129-149. New York: Springer.

Reynolds BA, Weiss S (1992a) Generation of neurons and astrocytes from isolated cells of the adult mammalian central nervous system. Science 255:1707-1710.

Reynolds BS, Weiss S (1992b) A multipotent EGF-responsive striatal embryonic progenitor cell produces neurons and astrocytes. J Neurosci 12:4565-4574.

Reynolds BA, Weiss S (1996) Clonal and population analyses demonstrate that an EGF-responsive mammalian embryonic precursor is a stem cell. Dev Biol 175:1-13.

Richards J, Kilpatrick TJ, Bartlett PF (1992) De novo generation of neuronal cells from the adult mouse brain. Proc Natl Acad Sci USA 89:8591-8595.

Satoh M, Yoshida T (1997) Promotion of neurogenesis in mouse olfactory neuronal progenitor cells by leukemia inhibitory factor in vitro. Neurosci Lett 225:165-168.

Sensenbrenner M, Deloulme JC, Gensburger C (1994) Proliferation of neuronal precursor cells from the central nervous system in culture. Rev Neurosci 5:43-53.

Suhonen JO, Peterson DA, Ray J, Gage FH (1996) Differentiation of adult hippocampus-derived progenitors into olfactory neurons in vivo. Nature 383:624-627.

Svendsen CN, Clarke DJ, Rosser AE, Dunnett SB (1996) Survival and differentiation of rat and human epidermal growth factor-responsive precursor cells following grafting into the lesioned adult central nervous system. Exp Neurol 137:376-388.

Svendsen CN, Caldwell MA, Shen J, ter Borg MG, Rosser A, Tyers P, Karimol S, Dunnett SB (1997) Long-term survival of human central nervous system progenitor cells transplanted into a rat model of Parkinson's disease. Exp Neurol 148:135-146.

Vescovi A, Reynolds BA, Fraser DD, Weiss S (1993) Basic fibroblast growth factor regulates the proliferative fate of both unipotent (neu- 
ronal) and bipotent (neuronal/astroglial) epidermal growth factorgenerated progenitor cells. Neuron 11:951-966.

Vicario-Abejon C, Cunningham MG, McKay RD (1995) Cerebellar precursors transplanted to the neonatal dentate gyrus express features characteristic of hippocampal neurons. Neuron 15:105-114.

Weiss S, Dunne C, Hewson J, Wohl C, Wheatley M, Peterson AC, Reynolds BA (1996a) Multipotential CNS stem cells are present in the adult mammalian spinal cord and ventricular neuroaxis. J Neurosci 16:7599-7609.

Weiss S, Reynolds BA, Vescovi AL, Morshead C, Craig CG, van-derKooy D (1996b) Is there a neural stem cell in the mammalian forebrain? Trends Neurosci 19:387-393.
Wells J, Vietje BP, Wells DG, Dunn ME (1988) Cell-sized microspheres in the hippocampus show cleavage planes and passive displacement. Brain Res Bull 21:601-605.

Winkler C, Fricker RA, Gates MA, Olsson M, Hammang JP, Carpenter MK, Björklund A (1998) Incorporation and glial differentiation of mouse EGF-responsive neural progenitor cells after transplantation into the embryonic rat brain. Mol Cell Neurosci 11:99-116.

Zigova T, Betarbet R, Soteres BJ, Brock S, Bakay RA, Luskin MB (1996) A comparison of the patterns of migration and the distribution of homotopically transplanted neonatal subventricular zone cells and heterotopically transplanted ventricular zone cells. Dev Biol 173:459-474. 